\begin{tabular}{|l|c|c|c|}
\hline Jus et civitas & $\begin{array}{c}\text { Vol. VIII(LXII) } \\
\text { No. 1/2021 }\end{array}$ & $35-42$ & $\begin{array}{c}\text { A Journal of Social and Legal } \\
\text { Studies }\end{array}$ \\
\hline
\end{tabular}

\title{
DISCRIMINATION. NEW CHALLENGES REGARDING HEALTH PROTECTION
}

\author{
Dragoș-Lucian Rădulescu
}

Petroleum - Gas University of Ploiesti, Bd. Bucharest, no. 39, Ploiesti, Romania

e-mail: dragosradulescu @ hotmail.com

DOI:10.51865/JETC.1.05

\begin{abstract}
The fight against discrimination is a general issue of the essence of the international institutions involved in the protection of human rights, democracy and the rule of law. This paper examines the application of the principles of discrimination, in scope to a better understanding of the fundamental concepts and the method of apply the control mechanisms. The main objective is reported to identify the international and national regulations on non-discrimination, as well as jurisprudential developments. The purpose of the research is related to highlighting the importance of recognizing the principle of non-discrimination in labor relations, in the event of the Covid pandemic, by analysing the role of state institutions, as well as the evolution of jurisprudential developments and the ways to combat discrimination.
\end{abstract}

Keywords: labor; discrimination; criteria; intersectionality; solidarity

\section{Introduction}

The main object of analysis of the paper was related to the assessment of illegal conduct and criteria protected in legal employment relationships starting with race, ethnic origin, belief or sex, in the event of the Covid pandemic.

The stereotype, related to the traditions of a certain society, contains the stigma applied without any motivation to those people who share similar characteristics, aiming to classify them into vulnerable groups, discrimination does not stop even in the event of the pandemic which should have induced social solidarity.

The direct ${ }^{1}$ or indirect unequal treatment in legal employment relationships, can be customized in the case of the Covid pandemic through the institution of intersectionality, in the case of the intersection of race, gender, nationality or religion criteria. Thus, the analysis of discrimination on the basis of ethnicity is a principal goal, but also are included aspects of employers' application of differential treatment based on several protected criteria, like religion and gender, which characterizes the mode of multiple discriminations.

\footnotetext{
${ }^{1}$ Țiclea, A., Tratat de dreptul muncii, Ed.Universul juridic, Bucureşti, 2005, p. 22.
} 
We can mainly see that, discrimination in employment is not immediately identified by employers and employees as an impermissible behavior ${ }^{2}$ that must be immediately sanctioned, given that in today's Romanian society persists certain level of stereotypes and manifestations of tolerance towards discriminatory behavior.

In this sense, according the Directives ${ }^{3}$ and to Convention no. 111 of the International Labor Organization of 1958 on discrimination in employment any particularities, exclusion or preference based on race, color, sex, religion, political opinion, national or social origin, having as its object or effect the non-compliance of equal opportunities are considered discriminatory, provided that they do not have as their object requirements justified. Discrimination presupposes manifestations of arbitrary exclusion, by noncompliance with the rules requiring the application of undifferentiated treatment to workers in comparable situations, although we believe that we must be in a process of social solidarity.

Sociologically, discrimination is reported to an unequal treatment applied to a group of people, without it being based on the lack of individual merits and without involving the real value of the group, based on purely subjective opinions.

The paper analyzes also the concept of positive discrimination, the latter being found in the case of preferential treatment granted especially to minority groups prone to inequality. As a special situation can be identified also an alternative of discrimination way self-imposed by employees, provided that they, knowing their specific situation, can proceed to internalize inequality, for example choosing not to participate in competitions or training stages from which I think they will be excluded anyway.

\section{Conceptual conclusions}

The concept of non-discrimination was initially related to the principle of equality, as an economic policy tool ${ }^{4}$, in the national laws of the states the specific rules being found at constitutional level and aimed at imposing equal conditions of access for all people to legal employment relationships.

In international and European documents ${ }^{5}$ and in national constitutions the approach has changed over time and the concept of non-discrimination was extended by the effect of the case law investigated by the Court of Justice of the European Union, ECHR or of national judicial practice.

The provisions prohibiting discrimination are more specific than the provisions on equality, and concern categories of persons who differ from others by a number of criteria, such as sex, age, religion, ethnic origin, nationality, which have acquired the character of protected criteria.

\footnotetext{
${ }^{2}$ Ţiclea A, Codul muncii, Ed.Universul juridic, Bucureşti, 2015, p.21.

${ }^{3}$ Muscalu L.M., Discriminarea în relaţiile de muncă, Ed.Hamangiu, Bucureşti, 2015, p.7.

${ }^{4}$ Marinescu, Delia-Mihaela, The evolution of concepts of equal opportunities and migration in the legislation of the European Union, articol publicat în proceedings ale Conferinței Stiintifice Internaționale STRATEGII XXI “Securitate Globală și Apărare Națională”, Universitatea Națională de Apărare "Carol I”, Scoala Doctorală, 25 -26 Iunie 2020, pg. 490-496.

${ }^{5}$ Ispas G.L., Fanc D., Dreptul instituţional al Uniunii Europene, Editura Hamangiu, București, 2019, p. 28.
} 
The need for non-discrimination rules must not only be related to the perspective of the existing subordination in the employer-employee relationship in legal employment relationships, but it is necessary to take into account the very foundation of citizens' rights and freedoms, given that contemporary society aims to combat discrimination and promote equality ${ }^{6}$.

In terms of protected criteria, in EU law ${ }^{7}$ the list of protected criteria is closed and includes race, nationality, ethnicity, language, religion, social status, belief, sex, sexual orientation, age, disability, chronic non-communicable disease, HIV infection or membership in a disadvantaged category. In this case, the Court of Justice of the European Union insists on the restrictive nature of this list, not admitting actions which have raised the issue of other criteria of discrimination (Cases C 13/05 Chacón Navas V Eurest Colectividades $\mathrm{SA}^{8}$ in which the criterion of disease was excluded and C 354/13 Kaltoft ${ }^{9}$ where obesity was considered a protected criterion by assimilation with the criterion of disability).

The European Convention on Human Rights, opts for an open list: "Exercising the rights and liberties recognized by the present Convention must be provided without differentiation on matters related to sex, race, color, language, religion, political or other types of opinions, national or social origin, belonging to a national minority, wealth, birth or any other situation".

Outside the EU, the use of somewhat different, in the case of Mexico the criteria of discrimination being non-limiting like homophobia, misogyny, xenophobia, racial segregation, intolerance and anti-Semitism.

With regard to the criterion of religion, in terms of non-discrimination there is a tendency to extend the application of protective rules to non-religious beliefs, like philosophical beliefs and practices, humanism, atheism, various belief systems, even when they are not widely accepted in society. There are particularities of the protected criterion of religion, which arise from a person's ability to change his/her religion or beliefs or to changes in manifestation or practice of faith or rituals in public or private spaces.

In the workplace, strategies to combat discrimination on the basis of religion have a component related to freedom of expression. Some seemingly neutral decisions were considered by the Court of Justice of the European Union to have the character of indirect discrimination, when they had an asymmetric effect on employees belonging to different religions. Thus, for example, the employer's decision to prohibit the wearing

\footnotetext{
${ }^{6}$ Szekely, Cătălina, Societatea civilă - o alternativă a justiției sociale?, articol publicat în Jus et Civitas A journal of Social and Legal Studie, vol II, Issue 1, no.1/2015, pg. 31-38.

7 Popescu Andrei, Dreptul internațional și European al muncii,Ediția 2,Editura C.H.Beck, București, 2008, p. 340.

${ }^{8}$ The Grand Chamber,judged on 11 July 2006, Sonia Chacón Navas împotriva Eurest Colectividades SA.

9 Cause C-354/13, judged by the Fourth Camber, 18 December 2014, text available online at http://curia.europa.eu/juris/document/document.jsf?text=\&docid=160935\&pageIndex=0\&doclang=ro\&m ode $=$ lst \&dir $=\&$ occ $=$ first $\&$ part $=1 \& \operatorname{cid}=701660$
} 
of religious insignia by employees was considered to affect members of the Muslim community to a greater extent than members of the Christian community.

In France a definition of race has not been accepted for historical or ethical reasons, so as not to lead to a true ethnicization and discrimination of some groups, which would eventually lead to the existence of phenomena of their rejection by a part of society, as a result contrary to international regulations. In this regard, in Denmark, Ireland, Austria, Portugal, Sweden and the United Kingdom do not mention descent, and Bulgaria, Germany, Spain, France, Italy, Latvia and Hungary do not mention color and descent. On the other hand, Malta and Slovenia do not include national descent and origin, Lithuania does not refer to color and ethnic origin, and the Czech Republic, Greece, the Netherlands, Poland and Romania do not consider national color, descent and origin to be applicable. The concepts of origin in the case of Estonia, France, Slovenia and Finland and of ethnic origin in Romania are similar to the term of descent, and the concept of nationality in Bulgaria and Lithuania is not similar to that of national origin.

The criteria of age in discrimination is very important in encouraging the access to employment, post-retirement policies and the prohibition of illegal dismissal.

Equal treatment for people with disabilities requires the introduction of special arrangements such as changes to equipment or the pace of work that implies the fulfillment of a positive obligation on the part of the employer to provide the necessary arrangements for carrying out the attributions. We are considering the right of employers not to recruit employees who do not have the necessary skills.

The protected criterion of sexual orientation refers to discriminatory behavior, when a particular person becomes the object of unequal treatment in society and at work, including sexual harassment which involves the ridicule or isolation of the victim at work, having the effect of damaging her dignity as a result of her sexual orientation.

Gender discrimination is based on the application of traditional social standards or prejudices related to the existence of low professional skills of women, although the globalization process marked the evolution towards the status of women workers, but did not determine the disappearance of discriminatory behaviors.

Objective justifications are very rare and did not permit the conduct of an employer to reject a person of a certain ethnicity for employment on the grounds that the job involves dealing with customers who would express opinions of reluctance or rejection towards members of this ethnic group.

The reference case was C-54/07 Feryn NV, which raised the issue of the discriminatory nature of the conduct of the representative of the autor who made job offers and at the same time made public statements in which he mentioned that future employees cannot be part of the immigrant category.

With regard to the existence of prejudice and discrimination at European level against migrants or ethnic groups, we can see that Europe is trying to redefine itself as a multicultural community, although public opinion hide some disadvantageous behaviors related to immigrants in employment area. 
The migration phenomenon of 2015 generated a wave of discriminatory and xenophobic manifestations, which the European Union tried to keep under control, although the foreigners who came from outside the European continent belonged not only to a different ethnicity but also to a different religion.

As a result, the fight against ethnic discrimination is constantly on the European Commission's agenda, in an attempt to identify new strategies for social integration and especially in the labor market and satisfying ${ }^{10}$ the provisions of Council Directives 2000/43/EC implementing the principle of equal treatment between persons irrespective of racial or ethnic origin.

As discrimination against Roma minorities, this ethnic group was appreciated as a true subclass influenced by a system of prejudices, being permanently subject to a structural discrimination that includes various fields, namely under-representation in the active population, limiting access to employment or vocational training, with de effect of transition to the informal economy.

Protective measures also include the obligation to establish and ensure the application of effective and proportionate sanctions for breaches of the provisions on compliance with the principle of equal treatment. These sanctions should also contain penal norms, because it is observed that the provisions of national labor laws are complemented, as a rule, in the domestic laws of states.

Penal regulation limit discriminatory conduct such as impeding the normal exercise of economic activities, refusal to hire or condition the job offer, incitement to discrimination, incitement to hatred or violence, segregation from a group or community, etc. being sanctioned with a criminal fine or imprisonment.

Such rules are found, for example, in Portuguese law and also provide for principal or additional penalties as prohibiting the exercise of certain professions or activities, suspension of authorizations or closure of establishments, and in Belgium variable compensation is imposed in case of non-pecuniary damage, depending on its severity.

\section{The case of multiple discriminations}

Multiple discriminations consist in the presence of several criteria, with the consequence of an exponential increase of the disadvantages felt by victims and derive from the intersection of various criteria such as language, religion and culture with others regarding, for example, racial and ethnic origin, in all cases involving differential treatment.

In defining multiple discriminations, one must take into account the differentiation from intersectionality, having as object the identification of several premises that are simultaneously inter-conditioned or with the concept of cumulative discrimination, which involves the potentiation of one criterion through the presence of another.

\footnotetext{
${ }^{10}$ Diaconu Nicoleta, Dreptul Uniunii Europene,Partea specială, Politicile comunitare, Editura Lumina Lex, București, 2007, p. 266-267.
} 
Cases of multiple discrimination include the areas of civil, social, political, economic life, as well as legal employment relationships, involving the violation of various categories of fundamental human rights and ultimately leading to the emergence of social, economic or status inequalities of individuals.

Multiple discriminations are based on the differential treatment applied by the use of different criteria, which, however, must be assessed simultaneously in terms of the seriousness of the author's conduct, however, there was no decrease in cases during the pandemic.

As a result, the identification of cases of multiple discriminations involves different interpretations related to the way in which several protected criteria are intertwined.

Recognition of multiple discrimination can also be linked to issues of recognition of group rights, in particular related to the past existence of an accepted system of oppression or inequality as a result of such membership, the introduction of positive measures aimed not only at eliminating the discrimination of a group of persons in society, but also of his/her discrimination in the sub-group to which he/she belongs.

\section{Conclusions}

Certain combinations of protected criteria are extremely common. Thus, ethnic origin and religion, ethnic origin and gender, or ethnic origin and social status - are often encountered simultaneously in practice, in the context of the same discriminatory behavior, because these characteristics allow an intersection.

The identification of a potential accumulation of the criteria of nationality, religion and ethnicity, but also the identity of these terms, is a problem for the interpretation of the law courts.

On the one hand, the recognition of discriminations with the involvement of the criterion of religion was amplified by the migration of the population of Islamic origin in the European space, an aspect that determined marginalization and unequal access to employment. On the other hand, the recognition of multiple discriminations also implies the special condition of disadvantaged groups, which implies new combat policies.

Last but not least, protection against discrimination is insufficient in national laws, because they continue to protect the individual only against discrimination by reference to a single protected characteristic (for example in the UK). It can be considered that in all cases, discrimination must involve the application of real and proportionate sanctions to the achievement of the purpose pursued by the legislator.

In conclusion, the new regulations aimed at limiting the spread of the Covid pandemic have not led to the long-awaited and necessary social solidarity, including the fight against discrimination, while maintaining the prejudices underlying discriminatory and xenophobic manifestations. 


\section{Bibliography}

1.Diaconu Nicoleta, Dreptul Uniunii Europene,Partea specială,Politicile comunitare, Editura Lumina Lex, București, 2007.

2.Ispas G.L., Fanc D., Dreptul instituțional al Uniunii Europene, Editura Hamangiu, București, 2019.

3.Popescu Andrei, Dreptul internațional și European al muncii,Ediția 2,Editura C.H.Beck, București, 2008.

4.Muscalu L.M., Discriminarea în relaţiile de muncă, Ed.Hamangiu, Bucureşti, 2015.

5.Marinescu, Delia-Mihaela, The evolution of concepts of equal opportunities and migration in the legislation of the European Union, articol publicat în proceedings ale Conferinți Stiintifice Internaționale STRATEGII XXI "Securitate Globală și Apărare Națională", Universitatea Națională de Apărare "Carol I", Scoala Doctorală, 25 -26 Iunie 2020, pp. 490-496.

6.Szekely, Cătălina, Societatea civilă - o alternativă a justiției sociale?, articol publicat în Jus et Civitas - A journal of Social and Legal Studie, vol II, Issue 1, no.1/2015, pp. 31-38.

7.Țiclea, A., Tratat de dreptul muncii, Editura Universul juridic, Bucureşti, 2005.

8.Țiclea A, Codul muncii, Editura Universul juridic, Bucureşti, 2015. 


\section{Discriminarea. noile provocări privind protejarea sănătății}

\section{Rezumat}

Combaterea discriminării reprezintă o problemă generală de esența instituțiilor internaționale implicate în protejarea drepturilor omului, democrației și statului de drept. Articolul analizează aplicarea principiilor de nediscriminare, în scopul înțelegerii conceptelor fundamentale și a modului de aplicare a mecanismelor de limitare. Obiectivul principal este legat de necesitatea prezentării reglementărilor internaționale și naționale în materie de nediscriminare, precum și evoluțiile jurisprudențiale. Scopul cercetării se raportează la recunoașterea importanței principiului nediscriminării în raporturile de muncă în situația apariției pandemiei Covid, precum și analizarea rolului instituțiilor statului, a jurisprudenței și a evoluției modalităților de combatere a discriminării. 